\title{
XLIII. Some experiments connected with the relations of caloric to magnetism
}

\author{
John Murray Esq. F.L.S. M.W.S.
}

To cite this article: John Murray Esq. F.L.S. M.W.S. (1823) XLIII. Some experiments connected with the relations of caloric to magnetism , Philosophical Magazine Series 1, 61:299, 207-207, DOI: $10.1080 / 14786442308644301$

To link to this article: http://dx.doi.org/10.1080/14786442308644301

曲 Published online: 29 Jul 2009.

Submit your article to this journal $\sqsubset \pi$

Џ Article views: 2

Q View related articles $₫$ 


\section{$\left[\begin{array}{ll}207 & \text { [ }\end{array}\right]$}

XLIII. Some Experiments connected with the Relations of Caloric to Magnetism. By John Murray, Esq. F.L.S. M.W.S. \&c.

\section{To the Editors of the Philosophical Magazine and Journal.}

I'T has not been determined whether the deviation of the

magnetic needle in M. Oërsted's interesting discovery, to the east or west according as it is posited above or below the uniting wire of the Voltaic circle, is to be attributed to the caloric evolved, or the electricity developed.

The following experiments seem to prove that the former is the efficient cause of this declination; and, as connected with the relations of heat to magnetism, the short and simple detail may be deemed of interest.

I used a long and slender magnetic needle taken from a theodolite. It was freely suspended by a thread of flos silk attached to its centre, and depended from a brass stand.

On bringing the flame of a spirit lamp eastroard of the south pole, it was primarily slightly repelled by the flame, and on the lamp being withdrawn the south pole moved toward the east to the amount of $45^{\circ}$ declination, and then slowly retrograded to its former position.

The flame being introduced westward of the south pole, seemed to attract the needle; and on being removed, the south pole deviated still more considerably toward the east, and finally slowly returned to its proper station.

The lamp was next brought westward of the north pole, and the flame seemed in the first instance to repell it; when the lamp was withdrawn, the north pole moved toward the rost, and the deviation amounted to $70^{\circ}$. After a proper interval it resumed its previous locality.

The flame, now brought eastward of the north pole, first exhibited an attractive influence; and on its removal the north pole slowly advanced westward, and at last retrograded.

The amount of the declination will of course vary, and will depend on the proximity and continuance of the flame.

The flame brought under the centre of the suspended needle, occasioned a circular motion.

I am, gentlemen, Your obedient servant,

Gloucester, March 1st, 1823.

J. Murray.

XLIV. $R e-$ 